慶應義塾大学学術情報リポジトリ

Keio Associated Repository of Academic resouces

\begin{tabular}{|c|l|}
\hline Title & $\begin{array}{l}\text { PHOTODYNAMIC THERAPY WITH PAD-S31, A NEW HYDROPHILIC CHLORIN PHOTOSENSITIZER, IN } \\
\text { AN ORTHOTOPIC RAT BLADDER TUMOR MODEL }\end{array}$ \\
\hline Sub Title & $\begin{array}{l}\text { 正所性ラット膀胱腫瘍モデルにおける新たな親水性クロリン光感受性物質であるPAD- } \\
\text { S31を用けた光線力学的療法 }\end{array}$ \\
\hline Author & 浅沼, 宏(Asanuma, Hiroshi) \\
\hline Publisher & 慶應医学会 \\
\hline Publication year & 2006 \\
\hline Jtitle & 慶應医学 (Journal of the Keio Medical Society). Vol.83, No.1 (2006. 3),p.27- \\
\hline JaLC DOI & \multicolumn{1}{|c|}{} \\
\hline Abstract & \\
\hline Notes & 号外 \\
\hline Genre & Journal Article \\
\hline URL & https://koara.lib.keio.ac.jp/xoonips/modules/xoonips/detail.php?koara_id=AN00069296-2006030 \\
& 2-0027 \\
\hline
\end{tabular}

慶應義塾大学学術情報リポジトリ(KOARA)に掲載されているコンテンツの著作権は、それぞれの著作者、学会または出版社/発行者に帰属し、その権利は著作権法によって 保護されています。引用にあたっては、著作権法を遵守してご利用ください。

The copyrights of content available on the KeiO Associated Repository of Academic resources (KOARA) belong to the respective authors, academic societies, or publishers/issuers, and these rights are protected by the Japanese Copyright Act. When quoting the content, please follow the Japanese copyright act. 


\title{
PHOTODYNAMIC THERAPY WITH PAD-S31, A NEW HYDROPHILIC CHLORIN PHOTOSENSITIZER, IN AN ORTHOTOPIC RAT BLADDER TUMOR MODEL
}

\author{
（正所性ラット膀胱腫劭モデルにおける新たな親水性クロリン光感受性物質である \\ PAD-S31を用いた光線力学的療法)
}

\begin{abstract}
浅沼宏
\end{abstract}
内容の要旨

\section{1. 绪管}

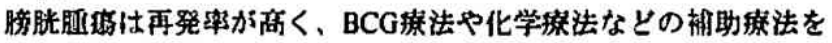
咹する症例が多いもののその勃果は未だ十分とはいえず新たな治能 方法の确立が急枒となっている。光称力学的解法 (photodynamic

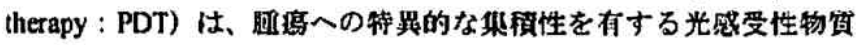

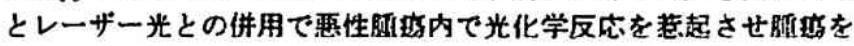

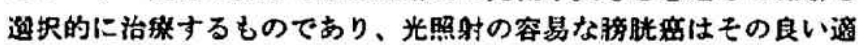

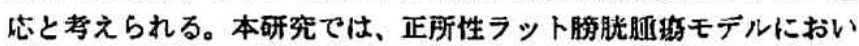

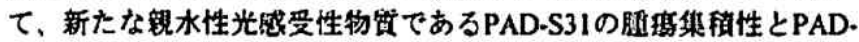

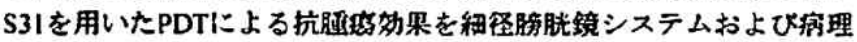
組曜検龺により検乾した。

2. 仏料・方法

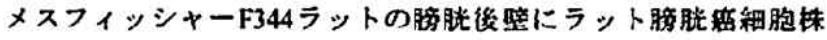
AY-27細胞 $\left(4 \times 10^{6}\right.$ 細胞/匹) を茫接注入し、5 日後に経尿道的内视

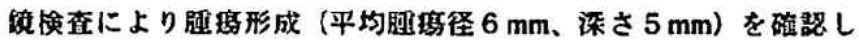

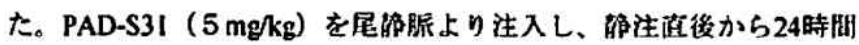

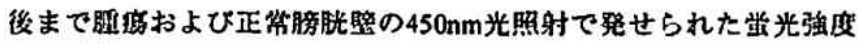

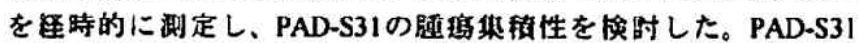
$(5 \mathrm{mg} / \mathrm{kg})$ を静注し、1 1 時閒後または 3 時間後に程尿逆的に扱入し た石英ファイバーによりダイオードレーザーを光源としてPDT（照 射バワー峾度: $100 \mathrm{~mW} / \mathrm{cm}^{2}$ 、照时エネルキー密度: $50 \sim 200 \mathrm{~J} / \mathrm{cm}^{2}$ ) を施行した。PDTによる抗概接効果を光照时 7 日後に膀胀鏡検查と

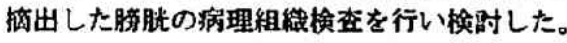

3. 結果

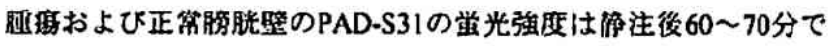

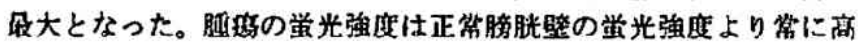
値を示し、注往後150〜240分には10停以上の值を示した。

PAD-S3! 能注 3 時間後 $50 \mathrm{~J} / \mathrm{cm}^{2}$ 照射 (6匹) では全てのラットで

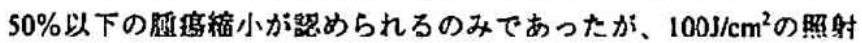

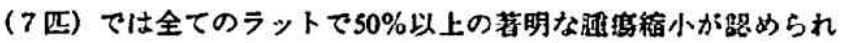

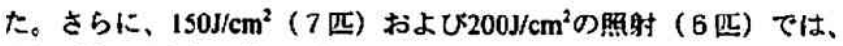
それぞれ4匹（57\%）および3匹（50\%）のラットで完全な堙新消

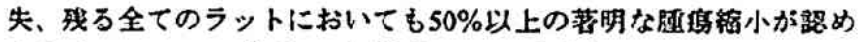
られた。PAD-S31解注 1 時间後 $100 \mathrm{~J} / \mathrm{cm}^{2}$ 照时 $(7$ 匹) では 1 匹

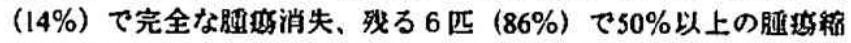

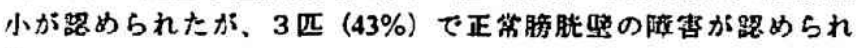
t。

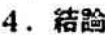

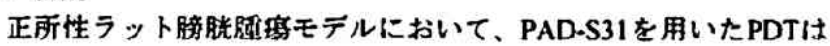

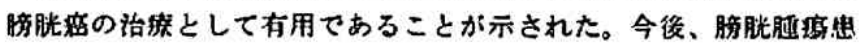
者への臨床结用が期待される。

\section{睮文丵査の要旨}

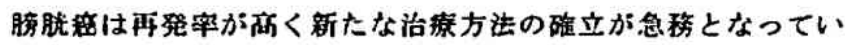
る。本研究では、ラット膀胱新由来AY-27稩胞を用いて正所珄ラッ 卜膀肤埂客モテルを作成し、新たな親水性光感受性物質であるPAD. S31の䀿然集甜住の検时とPAD-S31を用いたダイオードレーザーによ

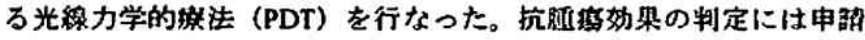

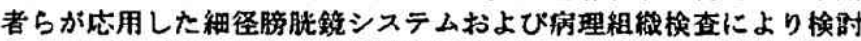

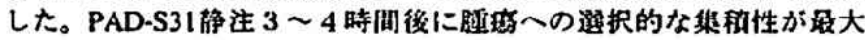

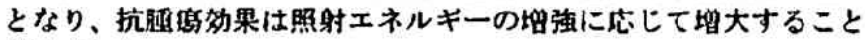
が示された。

萧查では、まず、PDTの特異性について質疑された。光根受性物

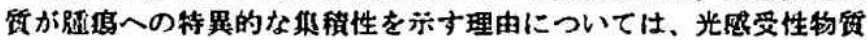

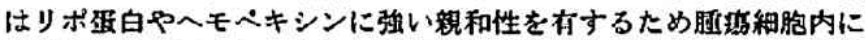

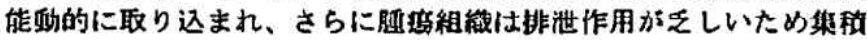

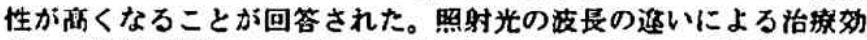

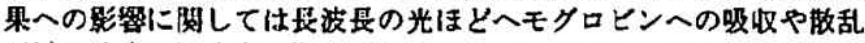

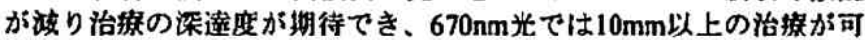
论であることが回答された。光琶受性物䓟の投与方法については、

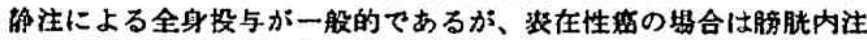
入が可能で膀胱蓄繒などの副作用が軽诚されることが回答された。

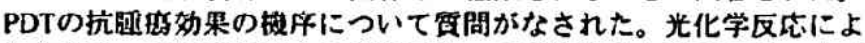

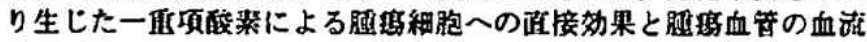
遮断効果が势えられることが回答されたが、なお堵死・アポトーシ スについての検封が望まれる旨助管があった。PAD-S31投与1時榻

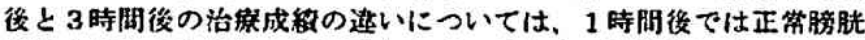
䛨にもPAD-S31が多く取り込まれているため3時間後に比べー部の

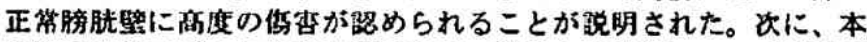

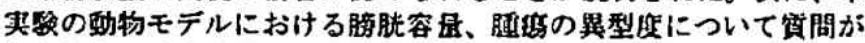
なされた。脖胱容衉は $0.5 \sim 0.8 \mathrm{ml}$ 、異型度はgrade $2 \sim 3$ と㙂明され

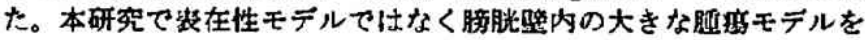
用いた理由について留閣がなされた。PAD-S31は670nmに吸収帶を

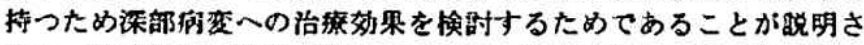

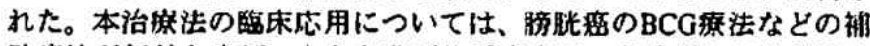

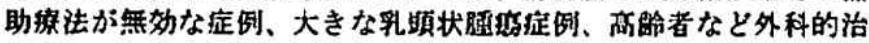

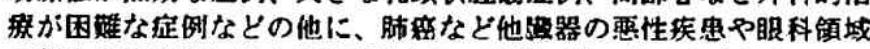
の新生血管狱变に対する治勃法として応用可能であるとされた。

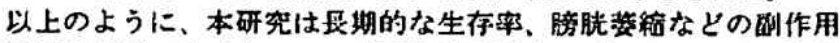

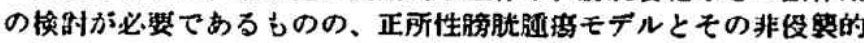

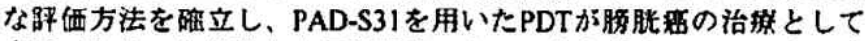
有用であり、今後監床匛用が期待できることを朋らかにした点で有 意我な研究であると硬された。

諭文䔯查担当者 主查 泌尿器科学 村井 勝

外科学 小林 紜一 病理学 坂元 好宇

彷理学阙田保典

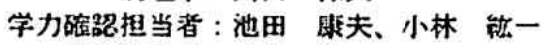
曾㭗委圆長 : 小林 紘一 